European Journal of Accounting, Auditing and Finance Research

Vol.8, No.2, pp.1-19, February 2020

Published by ECRTD-UK

Print ISSN: 2053-4086(Print), Online ISSN: 2053-4094(Online)

\title{
INTERNET FINANCE, MONETARY POLICY EFFECTIVENESS AND BANK CREDIT CHANNEL
}

\author{
Wu Jiyan', Zhou Meiyi² \\ ${ }^{1,2}$ International Business School, Jinan University, Zhuhai, Guangdong, China \\ *Correspondence: Wu Jiyan, International Business School, Jinan University, \\ Zhuhai, Guangdong, China \\ E-mail: $565558791 @$ qq.com
}

\begin{abstract}
With the information technology boom, the development of Internet Finance is justified to have a notable impact on the effectiveness of monetary policy. In allusion to the development of Internet Finance and changes in monetary policy from 2007 to 2018, this paper takes the bank credit transmission channels as an entry point and builds a Vector Error Correction (VEC) Model based on cointegration analysis. In this paper, we attain the influence of Internet Finance on intermediate targets and ultimate targets of monetary policy with the methods of Cointegration analysis, Granger test, VEC model and so forth by comparing bank credit channels and interest rate channels. The results of the research have revealed that Internet Finance weakens the transmission effect of monetary policy through bank credit channels, improves the market endogenous nature of money supply, which hinders the achievement of the ultimate goal of monetary policy.
\end{abstract}

KEYWORDS: internet finance, monetary policy, bank credit channel, VEC model

\section{INTRODUCTION}

With the rapid development of the Internet, the advantages of finance liberalization and simplification have accelerated Internet Finance dramatically. Although it is quite different from traditional finance and it is in its infancy, its advantages have been fully recognized by the public due to the appreciation by the government.

Internet Finance is a new type of financial business model built on the basis of traditional financial business modes, which extend its business to the Internet with the assistance of Internet technology. It has the functions of promoting accommodation of funds, payment and information circulation. Internet Finance breaks through the limitations of traditional intermediary platforms and gains more flexibility in time and space. In addition, it has higher transparency, faster information circulation, and more direct financial services. Nowadays, there are four main modes with mature development and large market shares in Internet Finance: Equity Crowdfunding, Internet Payments, Internet Funds and Online Lending. However, a great number of risks have also emerged while Internet Finance is experiencing significant growth. Owing to the soar of Internet Finance, the impact of the shadow banking system has spread to the real estate industry, local related 
Print ISSN: 2053-4086(Print), Online ISSN: 2053-4094(Online)

platforms and other areas, making the financial system more vulnerable. What's more, the increase of non-performing loan ratio and bond default rate exacerbates the turmoil in finance market. On top of that, Internet Finance has gradually penetrated into people's daily lives, thus making supervision more difficult. Only by gradually defusing the risks from Internet Finance and guiding the development of the real economy with financial technology, can Internet Finance achieve a healthy and sound development.

At present, scholars at home and abroad mainly conduct microcosmic researches on Internet Finance and those researches on the characteristics of Internet Finance and industry development are in the majority. Whereas, there are few studies concentrating on the impact of Internet Finance on monetary policy. Furthermore, many studies prefer the innovation of economic laws and ignore empirical analysis. Therefore, from a brand-new theoretical perspective, this paper plans to start from the Internet risk transmission mechanism with the ultimate goal of policy effects, launch an empirical research on the impact of Internet Finance on the effectiveness of monetary policy and propose specific suggestions concerning the improvement of monetary policy and financial supervision.

\section{LITERATURE}

The development of Internet Finance originated in western developed countries and people often call it "mobile finance" or "electronic finance". Tao Yana (2013) believes that Internet Finance is a new technology that promotes capital circulation. Different from the traditional financial industry, it combines new Internet technologies, such as searching skills, online payment skills and cloud computing skills ${ }^{[1]}$. From other perspectives, Yang Miaomiao (2015) pointed out that Internet Finance is a new type of organization related to financial institutions such as banks and other financial institutions ${ }^{[2]}$. Feng Xinyi (2018) gave a detailed definition of Internet Finance and thought that Internet Finance is a new financial platform which depends on Internet technology, such as integrated finance platform, information finance and fragmented finance ${ }^{[3]}$.

As the definition of Internet Finance has gradually clarified, many scholars have found that Internet Finance has a certain impact on monetary policy. The Bank for International Settlements (BIS) and the Group of Computer Experts (1996) discovered that similar to Internet payments, online currencies contribute to expand the currency multiplier ${ }^{[4]}$. David Cronin and Kevin Dowd (2001) figured out that the demand for base currency will decrease with the development of the networking technology on payment and settlement ${ }^{[5]}$. Slovinec (2006) reported that the development of Internet Finance will reduce the amount of traditional base currencies and the effects of monetary policy ${ }^{[6]}$. By contrast, Fujiki and Tanaka (2010) concluded that electronic money has made the demand for money substantially increased by saving transaction costs ${ }^{[7]}$. Likewise, domestic scholars have begun to study on Internet Finance recently. Zhong Huigen (2014) expounded from the opposite perspective that Internet Finance not only affects the actions of the central bank but also benefits the timeliness of monetary policy ${ }^{[11]}$. Yan Mina (2015) 
Print ISSN: 2053-4086(Print), Online ISSN: 2053-4094(Online)

stated that Internet Finance is predicted to raise the currency multiplier, thus enlarging money supply ${ }^{[12]}$. Additionally, the development of Internet Finance is likely to strengthen the endogenous market nature of money supply to some extent, which is negative to the function of monetary policy. Liu Lanyi, Qi Yanlong and Zhang Jingjia (2016) have shown that the sensitivity of interest rate on interbank lending rates is projected to be improved, and excessive fluctuations in the narrow currency multiplier will be caused too, thereby increasing the supply of broad money and the effectiveness of monetary policy ${ }^{[13]}$. From a new angle, Gu Haifeng and Zhu Lili (2018) suggested that current theories of monetary policy in China lack a unified and reasonable definition. Most scholars are limited to theoretical exploration and prefer to analyze the issues of supply, demand and efficiency without convincing empirical evidence ${ }^{[14]}$.

The research on the impact of Internet Finance on the effectiveness of monetary policy has stepped into a relatively mature phase. Liu Shasha (2016) built a VAR model to test the impact of monetary policy tools, such as reserves and interest rates, on the effectiveness of monetary policy ${ }^{[15]}$. The study illustrates that financial disintermediation has strengthened the effects of interest rate policy tools, including output and price level. Shen Juan (2017) conducted a theoretical derivation of the overall effect and influencing mechanism combining with theoretical and empirical research, and reached the conclusion that Internet Finance has overshadowed the effectiveness of monetary policy by weakening the effects of bank credit channels of monetary policy. That is, the overall effect does exist ${ }^{[16]}$. On one hand, the development of Internet Finance has pushed bank to extend into transactions in wealth management products, yet making it difficult for the central bank to exert monetary policy tools such as reserves. Zhan Minghua, Zhang Chengrui, and Shen Juan (2018) built a general equilibrium model for optimal decision-making with diversified objects including households, bank, and enterprises ${ }^{[17]}$, and analyzed how the movement of Internet Finance on the objects above affects the effectiveness of monetary policy from the central bank. On the other hand, the development of Internet Finance has affected the asset and liability structure of bank or enterprises under the consideration of capital circulation, which results in a further decline in the effectiveness of monetary policy. Xiong Zongjun (2018) introduced the scale of Internet Finance, loans, money supply(M2) and total output level into the Vector Error Correction model (VEC) ${ }^{[18]}$. The analysis demonstrates that the development of Internet Finance has caused fluctuations of money supply and a decrease in bank credit control power, and has also improved the instability of bank credit transmission channels.

Totally, foreign scholars study Internet Finance only based on electronic money. Nevertheless, the rocket of the Internet in China lately has led to the birth and boom of a wide range of Internet Finance products. Accordingly, foreign researches are not suitable for domestic situations. In terms of domestic researches, scholars have a preference to conduct microcosmic studies on Internet Finance theoretically and there are scarce quantitative empirical literatures, which are not enough to capture the long-term dynamic relationship between Internet Finance and monetary policy. As for empirical researches, most scholars select indicators from monetary policy 
European Journal of Accounting, Auditing and Finance Research

Vol.8, No.2, pp.1-19, February 2020

Published by ECRTD-UK

Print ISSN: 2053-4086(Print), Online ISSN: 2053-4094(Online)

tools, transmission mechanisms and Internet Finance tools and built VAR and VEC models for analysis. This paper deems that the development of Internet Finance affects the implementation of monetary policy from the central bank to a large extent. Nowadays, the finance market supervision system in China isn't perfect adequately and Internet Finance cannot be fully detected and managed, resulting in market endogenous and inefficient issues in the monetary policy. Thereby, this paper analyzes the real situation of Internet Finance in China more scientifically by theoretical and empirical researches and proposes more effective recommendations.

\section{METHODOLOGY}

\section{Index Selection}

Based on previous studies, this paper selected the indicators shown in Table 1.

Table 1. Indicators Illustration

\begin{tabular}{llll}
\hline Objects & Variables & Symbol \\
\hline Internet Finance development level & $\begin{array}{l}\text { Internet payment } \\
\text { transaction scale }\end{array}$ & PS \\
\hline & $\begin{array}{l}\text { Bank credit } \\
\text { transmission } \\
\text { channel }\end{array}$ & $\begin{array}{l}\text { RMB loans balance of } \\
\text { financial institutions }\end{array}$ & LB \\
\cline { 2 - 4 } $\begin{array}{l}\text { Monetary policy } \\
\text { transmission channels }\end{array}$ & $\begin{array}{l}\text { Interest rate } \\
\text { transmission } \\
\text { channel }\end{array}$ & Shibor & $\mathrm{R}$ \\
\hline \multirow{2}{*}{$\begin{array}{l}\text { Monetary policy } \\
\text { effectiveness }\end{array}$} & Intermediary goal & Money supply & M2 \\
\cline { 2 - 4 } & Ultimate goal & $\begin{array}{l}\text { Gross domestic } \\
\text { product }\end{array}$ & GDP \\
\cline { 2 - 4 } & Consumer price index & CPI \\
\hline
\end{tabular}

\section{Internet Finance developmental level:}

This paper selects the Internet payment transaction scale (PS) as the indicator on behalf of the developmental level of Internet Finance. Macroscopically judging the scale of Internet Finance over the years helps comprehensively investigate the developmental level of Internet Finance.

\section{Monetary policy transmission channels:}

This paper selects RMB loans balance of financial institutions (LB) and Shibor (R) as indicators to represent two different transmission channels that effect the monetary policy. For one thing, the development of Internet Finance has resulted in many capital flows not being regulated by the central bank, which has a certain influence on the regulatory objectives of the central bank, such as the currency multiplier. The decrease in loan balances of financial institutions, especially commercial banks, shows that the development of Internet Finance can absorb some 
European Journal of Accounting, Auditing and Finance Research

Vol.8, No.2, pp.1-19, February 2020

Published by ECRTD-UK

Print ISSN: 2053-4086(Print), Online ISSN: 2053-4094(Online)

loans. Therefore, RMB loan balances of financial institutions can better quantify the extent to which Internet Finance affects bank credit channels. For another, Shibor is the most representative interest rate in the developed currency market, which can more accurately describe the change in the interest rate levels than others.

\section{The effectiveness of monetary policy:}

This paper selects money supply (M2), gross domestic products (GDP), and consumer price index (CPI) to represent the effectiveness of monetary policy. The effect of monetary policy is transmitted to the intermediary goals mainly through the formulation of policy tools and finally the ultimate goals are achieved. The general intermediary targets mainly include money supply and long-term interest rates. There are four main policy objectives, including economic growth, price stability, full employment, and payments balance. The development of Internet Finance affects money supply primarily through the effects on financial channels frictions. Hence, this paper selects M2 to represent the intermediate goal of monetary policy. In addition, in view of bank credit channels, the development of Internet Finance mainly affects the mode and the scale of deposit and loan. Then, it has an incluence on social productivity, thus affecting economic growth and price stability. Thereby, this paper selects GDP and CPI to represent the ultimate goal of monetary policy.

\section{Data description and processing}

This paper uses the data between the first quarter of 2007 and the fourth quarter of 2018 and takes the quarter as the data frequency. The data comes from the National Statistical Yearbook, the People's Bank of China, and iResearch. A total of 322 data (six indicators, 46 data for each) are included in the research.

In this paper, the logarithmic data is firstly used to eliminate the volatility and heteroscedasticity of economic data. What' more, the data of CPI is further processed by setting the year of 2000 as the base (100) and calculating quarterly data for each year in the future to ensure consistent statistical methods with other indicators.

According to the time series chart made by EViews8.0, it is found that GDP has obvious seasonality shown in Figure 1, while other variables don't. Accordingly, the data of GDP is seasonally adjusted with the method of multiplication in Figure 1.

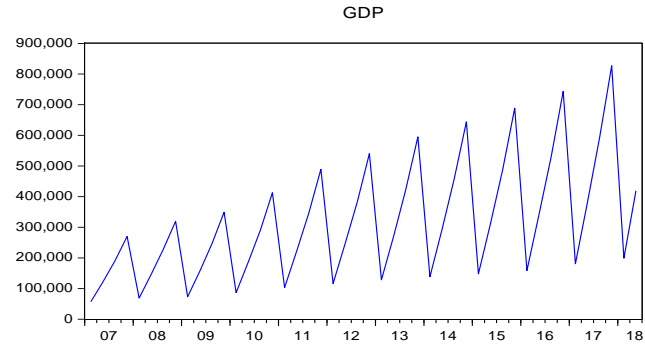

Figure 1. GDP trend in 2007-2018 in 2007-2018

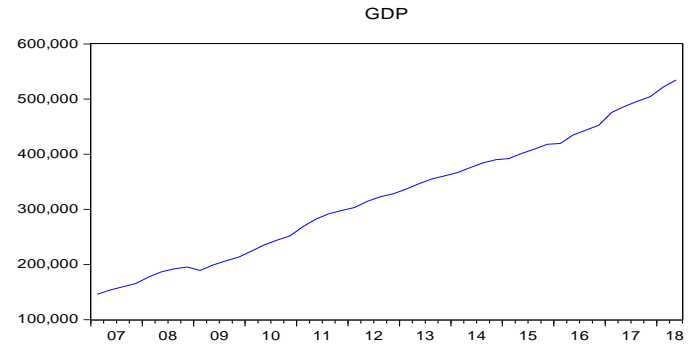

Figure 2. adjusted GDP trend 
European Journal of Accounting, Auditing and Finance Research

Vol.8, No.2, pp.1-19, February 2020

Published by ECRTD-UK

Print ISSN: 2053-4086(Print), Online ISSN: 2053-4094(Online)

\section{Econometric model establishment}

This paper intends to utilize the Vector Autoregressive model with co-integration constraints (Vector Error Correction model) for empirical analysis.

\section{Step1: Augmented Dickey-Fuller Test}

As the basis of the econometric model, Augmented Dickey-Fuller test is to examine whether the time series are stable. The formulas are as follow:

$$
\begin{gathered}
\Delta Y_{t}=c+\rho Y_{t-1}+\sum_{i=2}^{n} \phi_{i} \Delta Y_{t-i+1}+\varepsilon_{t} \\
\left\{\begin{array}{l}
\rho=\left(\sum_{i=1}^{n} \alpha_{i}\right)-1 \\
\phi_{i}=-\sum_{j=i}^{n} \alpha_{j}
\end{array}\right.
\end{gathered}
$$

Among them,

$$
Y_{t}=c+\alpha_{1} Y_{t-1}+\cdots+\alpha_{n} Y_{t-n}+\varepsilon_{t}
$$

\section{Step2: Cointegration Analysis}

Since the main research object is the relationship between Internet Finance and the indicators of monetary policy, there is only one cointegration relationship at most. The Engle-Granger test can be used to examine cointegration relationships between variables.

\section{Step3: Granger Causality Test}

Step 2 does not specify which variable affects other variables. For this reason, this paper uses Granger Causality test to determine the concrete causality between variables. The formulas are as follows:

$$
\left\{\begin{array}{c}
Y_{t}=\delta+\sum_{i=1}^{m} \alpha_{i} Y_{t-i}+\sum_{i=1}^{m} \beta_{i} X_{t-i}+\varepsilon_{t} \ldots . . \mathrm{RSS}_{U} \\
Y_{t}=\delta^{\prime}+\sum_{i=1}^{m} \alpha_{i} Y_{t-i}+v_{t} \ldots . . \mathrm{RSS}_{R} \\
F=\frac{\left(\mathrm{RSS}_{R}-\mathrm{RSS}_{U}\right) / m}{\mathrm{RSS}_{U} /(n-k)}
\end{array}\right.
$$

\section{Step4: VEC model establishment}

According to related literatures, the lag order is commonly judged by several standards including AIC information criteria, SIC information criteria and so forth. This paper first builds a VAR model with sufficient lag orders and judge the lag order from the combination of six methods. If the selected lag order satisfies three or more criteria, it is the optimal order. Afterwards, a Vector Error Correction model 
European Journal of Accounting, Auditing and Finance Research

Vol.8, No.2, pp.1-19, February 2020

Published by ECRTD-UK

Print ISSN: 2053-4086(Print), Online ISSN: 2053-4094(Online)

is built based on the co-integration relationship. Finally, the short-term dynamic equation is established on the basis of the long-term equilibrium equation. In accordance with the short-term dynamic relationship, the VEC model can be built as follows:

$$
\left\{\begin{array}{l}
\Delta Y=\alpha E C M_{t-1}+\beta \Delta Y_{t-1}+\varepsilon_{t} \\
\Delta Y=\left(\begin{array}{l}
\Delta \ln (X) \\
\Delta \ln (Y)
\end{array}\right)
\end{array}\right.
$$

Among them, the difference term is mainly how the variables are adjusted according to the past data. That is, it shows the effect of two variables on each other.

\section{Step 5: Impulse Response Function and Variance Decomposition}

The Impulse Response Function records the impact of one variable on another variable after the change, which can intuitively illustrate the dynamic influencing path over a long period of time.

Variance Decomposition can also clearly show the extent to which the variation of each random interference term can be explained by other random error terms.

\section{RESULTS AND ANALYSIS}

\section{Augmented Dickey-Fuller Test}

The results of Augmented Dickey-Fuller test are shown in Table 2.

Table 2. the Result of Augmented Dickey-Fuller Test

\begin{tabular}{lllllll}
\hline Variable & $\begin{array}{l}\text { ADF test } \\
\mathrm{s}\end{array}$ & \multicolumn{2}{l}{ Confidence level } & \multirow{2}{*}{$\mathrm{P}$} & stationarity \\
\cline { 3 - 6 } value & 0.01 & 0.05 & 0.1 & & \\
\hline $\mathrm{PS}$ & 4.1231 & - & - & - & 1.000 & non- \\
& & 3.6268 & 2.9458 & 2.6115 & 0 & stationary \\
$\mathrm{LB}$ & 2.9942 & - & - & - & 1.000 & non- \\
& & 3.5925 & 2.9314 & 2.6039 & 0 & stationary \\
$\mathrm{R}$ & -2.4511 & - & - & - & 0.134 & non- \\
& & 3.5847 & 2.9281 & 2.6022 & 1 & stationary \\
$\mathrm{M} 2$ & -2.5960 & - & - & - & 1.000 & non- \\
& & 3.6105 & 2.9390 & 2.6079 & 0 & stationary \\
GDP & 2.0014 & - & - & - & 0.999 & non- \\
& & 3.5847 & 2.9281 & 2.6022 & 8 & stationary \\
CPI & \multirow{2}{*}{1.0657} & - & - & - & 0.996 & non- \\
& & 3.6210 & 2.9434 & 2.6103 & 5 & stationary \\
\hline
\end{tabular}

According to Table 2, the original time series of six variables are non-stationary series, which indicates that economic variables have been disturbed by many different factors in the past ten years and they show a trend of fluctuation. As a result, the original time series is turned to new series with a first order difference and the ADF test is performed again. The adjusted test results are shown in Table 3. 
European Journal of Accounting, Auditing and Finance Research

Vol.8, No.2, pp.1-19, February 2020

Published by ECRTD-UK

Print ISSN: 2053-4086(Print), Online ISSN: 2053-4094(Online)

Table 3. the Result of Augmented Dickey-Fuller Test after Adjusted

\begin{tabular}{|c|c|c|c|c|c|c|}
\hline \multirow{2}{*}{ Variables } & \multirow{2}{*}{$\begin{array}{l}\text { ADF test } \\
\text { value }\end{array}$} & \multicolumn{3}{|c|}{ Confidence level } & \multirow{2}{*}{$\mathrm{P}$} & \multirow{2}{*}{$\begin{array}{l}\text { stationarit } \\
\mathrm{y}\end{array}$} \\
\hline & & 0.01 & 0.05 & 0.1 & & \\
\hline PS $(-1)$ & -2.918343 & $\begin{array}{l}-58851 \\
\end{array}$ & 2.92973 & $\begin{array}{l}- \\
2.60306\end{array}$ & $\begin{array}{l}0.051 \\
3\end{array}$ & stationary \\
\hline $\mathrm{LB}(-1)$ & -8.126277 & $\begin{array}{l}- \\
3.59246\end{array}$ & -2.9314 & $\begin{array}{l}- \\
2.60394\end{array}$ & $\begin{array}{l}0.000 \\
0\end{array}$ & stationary \\
\hline $\mathrm{R}(-1)$ & -7.257589 & $\begin{array}{l}- \\
3.58851\end{array}$ & $-\overline{2.92973}$ & $-\overline{2.60306}$ & $\begin{array}{l}0.000 \\
0\end{array}$ & stationary \\
\hline M2 (-1) & -3.352104 & $\begin{array}{l}- \\
3.61559\end{array}$ & $-\overline{2.94115}$ & $-\overline{2.60907}$ & $\begin{array}{l}0.019 \\
3\end{array}$ & stationary \\
\hline $\operatorname{GDP}(-1)$ & -5.369558 & $-\overline{3.58851}$ & $-\overline{2.92973}$ & $-\overline{2.60306}$ & $\begin{array}{l}0.000 \\
1\end{array}$ & stationary \\
\hline $\begin{array}{l}\text { CPI (- } \\
1)\end{array}$ & -2.692182 & $\begin{array}{l}- \\
3.62102\end{array}$ & $\begin{array}{l}- \\
2.94343\end{array}$ & $\begin{array}{l}- \\
2.61026\end{array}$ & $\begin{array}{l}0.085 \\
2\end{array}$ & stationary \\
\hline
\end{tabular}

As shown in Table 3, the time series with a first order difference are stable sequences, which demonstrates that all the growth rates of variables are stable and the general development trend is relatively stationary.

\section{Cointegration analysis}

Initially, we perform the least squares method on LB, R, M2, GDP and CPI with PS, and conduct the ADF test on the residual sequences from regression to estimate the stability of the residual sequences. The results of the test are shown in Table 4.

Table 4. the Result of ADF Rest in the Regression Residual Sequences

\begin{tabular}{llllll}
\hline \multirow{2}{*}{ PS } & \multirow{2}{*}{ ADF test value } & \multicolumn{3}{l}{ Confidence level } & \multirow{2}{*}{ stationarity } \\
\cline { 3 - 5 } & & $1 \% *$ & $5 \% * *$ & $10 \% * * *$ & \\
\hline LB & -2.203372 & -2.624 & -1.949 & -1.612 & stationary ** \\
R & 2.194792 & -2.624 & -1.949 & -1.612 & stationary $* *$ \\
M2 & -2.101333 & -2.624 & -1.949 & -1.612 & stationary ** \\
GDP & -1.980063 & -2.624 & -1.949 & -1.612 & stationary ** \\
CPI & -2.823206 & -2.624 & -1.949 & -1.612 & stationary $*$ \\
\hline
\end{tabular}

It can be clearly seen from Table 4 that the residual sequences are all stationary, which shows that there is a long-term cointegration relationship between PS and other variables, indicating that they have a common random trend. 
European Journal of Accounting, Auditing and Finance Research

Vol.8, No.2, pp.1-19, February 2020

Published by ECRTD-UK

Print ISSN: 2053-4086(Print), Online ISSN: 2053-4094(Online)

\section{Granger Causality test}

Table 5. the Result of Granger Causality Test

\begin{tabular}{llll}
\hline The null hypothesis & F & P & Whether to reject the null hypothesis \\
\hline $\begin{array}{l}\text { LB does not Granger Cause } \\
\text { PS }\end{array}$ & 5.24232 & 0.0096 & YES \\
$\begin{array}{l}\text { PS does not Granger Cause } \\
\text { LB }\end{array}$ & 4.64393 & 0.0155 & YES \\
\hline $\begin{array}{l}\text { R does not Granger Cause PS } \\
\text { PS does not Granger Cause R }\end{array}$ & 0.54393 & 0.5848 & NO \\
\hline $\begin{array}{l}\text { M2 does not Granger Cause } \\
\text { PS }\end{array}$ & 6.05293 & 0.0051 & YES \\
$\begin{array}{l}\text { PS does not Granger Cause } \\
\text { M2 }\end{array}$ & 10.9788 & 0.0002 & YES \\
\hline $\begin{array}{l}\text { GDP does not Granger Cause } \\
\text { PS }\end{array}$ & 4.28709 & 0.0208 & YES \\
$\begin{array}{l}\text { PS does not Granger Cause } \\
\text { GDP }\end{array}$ & 1.64314 & 0.2065 & NO \\
$\begin{array}{l}\text { CPI does not Granger Cause } \\
\text { PS }\end{array}$ & 0.80885 & 0.4527 & NO \\
$\begin{array}{l}\text { PS does not Granger Cause } \\
\text { CPI }\end{array}$ & 4.47145 & 0.0178 & YES \\
\hline
\end{tabular}

As can be seen from Table 5, PS is the Granger cause of LB, M2, and CPI, but not the Granger cause of R and GDP. For one thing, it gives the information that the development of Internet Finance makes money supply increase by raising the currency multiplier and reducing financial friction, and that the growth in the price has a certain influence on social deposits and loans at the same time. For another, Internet Finance cannot substantially promote the marketization of interest rates, illustrating that Internet Finance affects the effectiveness of monetary policy through bank credit transmission channels instead of interest rate transmission channels. Additionally, Internet Finance cannot substantially stimulate domestic economic growth. It is also found that both LB and M2 are Granger cause for PS reciprocally, showing that there is an interaction mechanism between them. GDP is the Granger cause of PS, which indicates that the recent economic mode has pushed the development of Internet Finance to some extent. 
European Journal of Accounting, Auditing and Finance Research

Vol.8, No.2, pp.1-19, February 2020

Published by ECRTD-UK

Print ISSN: 2053-4086(Print), Online ISSN: 2053-4094(Online)

\section{VEC Model between variables}

\section{$V E C$ model between $P S$ and $L B$}

Table 6. Optimal Lag Order Selection

\begin{tabular}{lllllll}
\hline Lag & LogL & LR & FPE & AIC & SC & HQ \\
\hline 0 & -1040.635 & NA & $1.25 \mathrm{E}^{+19}$ & 49.64929 & 49.73204 & 49.67962 \\
1 & -849.6824 & 354.6264 & $1.70 \mathrm{E}^{+15}$ & 40.74678 & 40.99502 & 40.83777 \\
2 & -847.051 & 4.636317 & $1.82 \mathrm{E}^{+15}$ & 40.81195 & 41.22568 & 40.9636 \\
3 & -830.9206 & $26.88403 *$ & $1.03 \mathrm{e}^{+15 *}$ & $40.23431^{*}$ & $40.81354 *$ & $40.44662^{*}$ \\
4 & -829.5026 & 2.228252 & $1.17 \mathrm{E}^{+15}$ & 40.35727 & 41.10198 & 40.63024 \\
\hline
\end{tabular}

It is clear from Table 6 that the optimal lag order for building a VAR model is 3rd order, so the optimal lag order for building a VEC model is 2 nd order. For all the VEC models, AR root test is performed to examine the stability of all the models, the results of which are shown in Figure 6.1. It shows that the VEC model built with the interest rate $\mathrm{R}$ is not stable while others are stable, demonstrating that the Vector Error Correction model in this paper is in line with theoretical expectations.

The results of Cointegration test reports that there is a long-term equilibrium relationship between PS and LB, but this equilibrium is not fixed. Once the stable state is destroyed, the system will return to the stable state through the error correction mechanism. Same below. The following co-integration equation between PS and LB with the error correction term is estimated by Eviews8.0.

$$
E C M_{t-1}=L B-5.896512 P S-856524.5
$$

Based on the short-term dynamic relationship, the Vector Error Correction model is built as follows:

$$
\left(\begin{array}{l}
\Delta L B_{t} \\
\Delta P S_{t}
\end{array}\right)=\left(\begin{array}{l}
0.027 \\
0.004
\end{array}\right) E C M_{t-1}+\left(\begin{array}{l}
0.1362 .501 \\
0.0180 .399
\end{array}\right)\left(\begin{array}{l}
\Delta L B_{t-1} \\
\Delta P S_{t-1}
\end{array}\right)+\left(\begin{array}{c}
-0.743-1.537 \\
0.00050 .2054
\end{array}\right)\left(\begin{array}{l}
\Delta L B_{t-2} \\
\Delta P S_{t-2}
\end{array}\right)+\left(\begin{array}{l}
47992.91 \\
961.2715
\end{array}\right)
$$


Print ISSN: 2053-4086(Print), Online ISSN: 2053-4094(Online)

Among them, the difference term represents the effect of short-term fluctuations and the explanatory variable in the VEC model is a lag term with an error correction term (ECMt-1) added. Same below. According to the cointegration equation, the elasticity of LB on PS is 5.986512, which means that for every change of $1 \%$ in PS, LB will change by $5.89 \%$ in the long run, indicating that the impact of Internet Finance development on loans is huge in long-term period. In the short term, the estimated coefficients of the error correction term (ECMt-1) demonstrates that under the condition of unchanged PS, the change of LB in period $t$ can eliminate the non-error equilibrium by $2.7 \%$ in the previous period. With the same LB, the change of PS in period $t$ can remove the non-error equilibrium by $0.4 \%$ in the last period. Regarding to the difference term, the first-phase regression coefficients of LB and PS are the largest, which shows that the first-phase lag effect is more significant. Every increase of one percentage point in LB will make PS in the lag 1 period rise by 0.018 percentage point. In a like manner, each increase of percentage point in PS will make LB in the lag 1 period climb up by 2.501 percentage points.
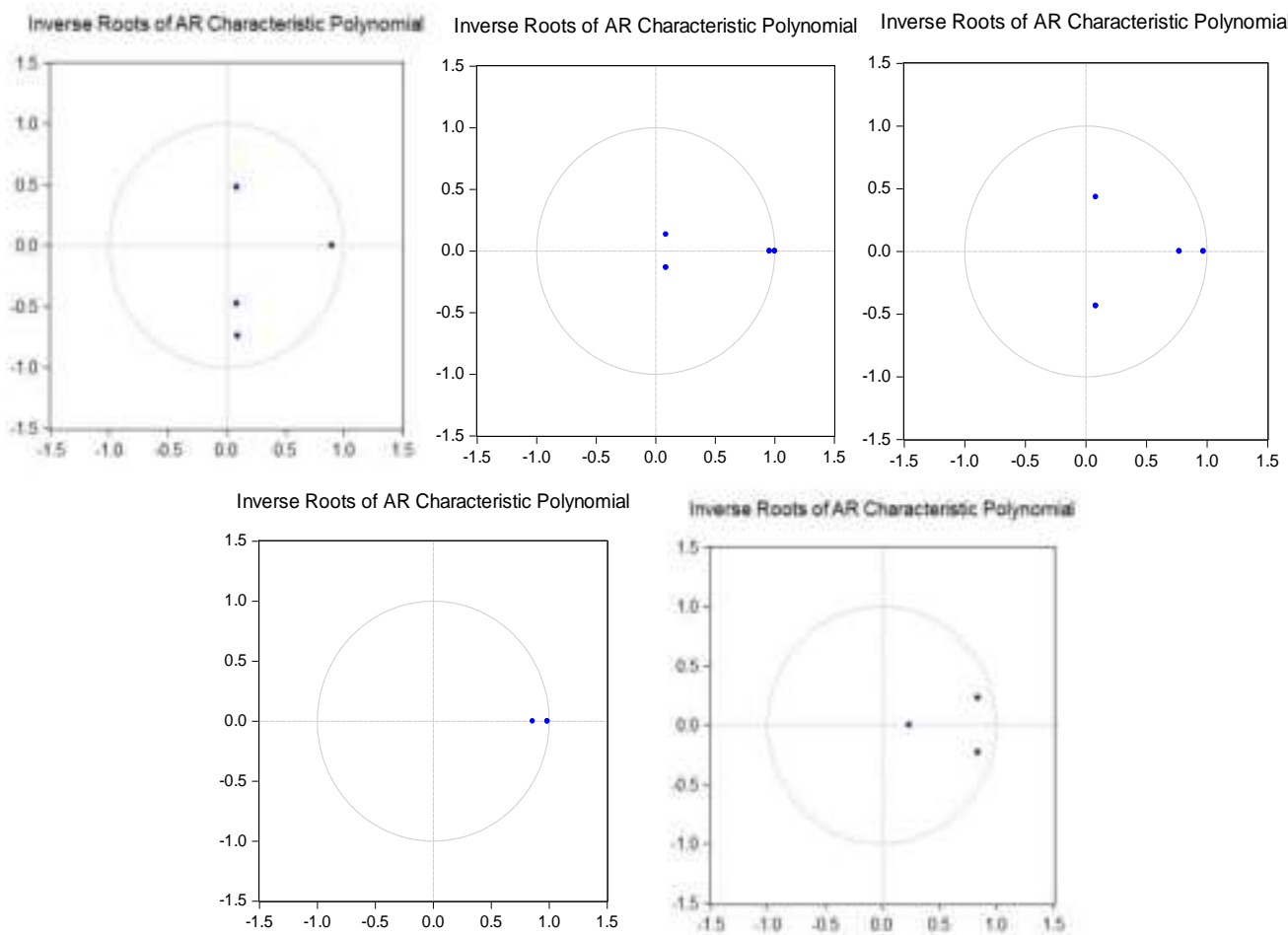

Figure 3. the Result of AR Root Test in All the VEC Model

\section{VEC Model between PS and R}

As above, it can be found that the optimal lag order of the VEC model is first order and the VEC (1) model is non-stationary. The co-integration equation between PS and $\mathrm{R}$ with the error correction term is as follows :

$$
E C M_{t-1}=R-7.81 \mathrm{E}-05 P S-0.815405
$$


Print ISSN: 2053-4086(Print), Online ISSN: 2053-4094(Online)

Based on the short-term dynamic relationship, the Vector Error Correction model is built as follows:

$$
\left(\begin{array}{l}
\Delta R_{t} \\
\Delta P S_{t}
\end{array}\right)=\left(\begin{array}{l}
-0.0447 \\
-475.65
\end{array}\right) E C M_{t-1}+\left(\begin{array}{cc}
-0.084 & -1.77 \mathrm{E}-05 \\
700.93 & 0.366949
\end{array}\right)\left(\begin{array}{l}
\Delta R_{t-1} \\
\Delta P S_{t-1}
\end{array}\right)+\left(\begin{array}{l}
0.042411 \\
1198.072
\end{array}\right)
$$

Shown in the co-integration equation, the elasticity of R on PS is 0.000078 , which represents that for every change of $1 \%$ in PS, LB will change by $0.000078 \%$ in the long run, illustrating that the impact of Internet Finance development on interest rates is tiny in the long term. In the short-term period, the coefficient estimates of the error correction term (ECMt-1) give the information that when short-term fluctuations deviate from the long-term equilibrium due to external disturbance factors, the error correction term will actively adjust back to the long-term equilibrium state with a strength of 0.0447 . That is, the change of $\mathrm{R}$ in period $t$ can eliminate the non-error equilibrium by $4.47 \%$ in the previous period. In regard to difference terms, the coefficients of R and PS in the first-phase regression are 700.93 and 0.0000177 , respectively. It means that $\mathrm{R}$ has a remarkable impact on PS. For every rise of one percentage point in R, PS in the lag 1 period will increase by 700.93 percentage points. On the contrary, the effect of PS on R is small no matter in the long or short term.

\section{VEC Model between PS and M2}

As mentioned above, it is evident that the optimal lag order of the VEC model is first order and the VEC (1) model is stationary. The co-integration equation between PS and M2 with error correction terms is as follows:

$$
E C M_{t-1}=M 2-0.740567 P S-85518.62
$$

Based on the short-term dynamic relationship, the Vector Error Correction model is built as follows:

$\left(\begin{array}{l}\Delta M 2_{t} \\ \Delta P S_{t}\end{array}\right)=\left(\begin{array}{l}0.0244 \\ 0.0386\end{array}\right) E C M_{t-1}+\left(\begin{array}{c}-0.0480 .032 \\ 0.00520 .368\end{array}\right)\left(\begin{array}{l}\Delta M 2_{t-1} \\ \Delta P S_{t-1}\end{array}\right)+\left(\begin{array}{c}-0.5450 .1051 \\ -0.279-0.096\end{array}\right)\left(\begin{array}{l}\Delta M 2_{t-2} \\ \Delta P S_{t-2}\end{array}\right)+\left(\begin{array}{l}4804.941 \\ 518.5191\end{array}\right)(12$

Reflected from the co-integration equation, the elasticity of M2 on PS is 0.740457 , which suggests that for every change of $1 \%$ in PS, M2 will rise by $0.74 \%$ in the longterm period, demonstrating that the development of Internet Finance adversely influences money supply(M2) in the long run and causes a large fluctuation in M2. In the short term, the estimated coefficients of the error correction term (ECMt-1) show that when short-term fluctuations deviate from the long-term equilibrium because of external interference factors, the error correction term can initiatively return to the long-term equilibrium state with a strength of 0.0244 . That is to say, the change of M2 in period $t$ can eliminate the non-error equilibrium by $2.44 \%$ in the last period. With respect to the difference term, the coefficients of M2 and PS in the two-phase regression are the largest, and the two-phase lag effect is more noticeable. Every increase of one percentage point in M2 will reduce PS in the lag 2 period by 0.279 percentage point. Likewise, every increase of one percentage point in PS will make M2 in the lag 2 periods increase by 0.1051 percentage point. Overall, the 
European Journal of Accounting, Auditing and Finance Research

Vol.8, No.2, pp.1-19, February 2020

Published by ECRTD-UK

Print ISSN: 2053-4086(Print), Online ISSN: 2053-4094(Online)

development of Internet Finance has caused great fluctuations in money supply and affected the controllability of monetary policy, thereby reducing the effectiveness of monetary policy.

\section{VEC model between PS and GDP}

With the same method of judgement, the optimal lag order of the VEC model is first order and the VEC (1) model is stationary. The co-integration equation with error correction terms between PS and GDP is as follows:

$$
E C M_{t-1}=G D P-2.680459 P S-375994.1
$$

Based on the short-term dynamic relationship, the Vector Error Correction model is built as follows :

$$
\left(\begin{array}{l}
\Delta G D P_{t} \\
\Delta P S_{t}
\end{array}\right)=\left(\begin{array}{l}
0.009 \\
0.005
\end{array}\right) E C M_{t-1}+\left(\begin{array}{cc}
0.072 & -0.119 \\
0.132 & 0.345
\end{array}\right)\left(\begin{array}{l}
\Delta G D P_{t-1} \\
\Delta P S_{t-1}
\end{array}\right)+\left(\begin{array}{l}
8240.818 \\
123.3640
\end{array}\right)
$$

Seen in the co-integration equation, the elasticity of GDP on PS is 2.680459 , which concludes that for every change of $1 \%$ in PS, M2 will increase by $2.68 \%$ in the long run, indicating that the development of Internet Finance has a considerable impetus in promoting economic growth in the long run. In the short term, the coefficient estimations of the error correction term (ECMt-1) show that when short-term fluctuations deviate from the long-term equilibrium owing to external interference factors, the error correction term will adjust back to the long-term equilibrium state with a strength of 0.009 on its own initiative. In other words, the change in GDP during period $t$ can reduce the non-error equilibrium by $0.9 \%$ in the previous period. As for the difference term, the coefficients of GDP and PS in the first-phase regression are 0.132 and -0.119 , collectively, demonstrating that there is an interactive mechanism between GDP and PS. Each increase of one percentage point in GDP will make PS in the lag 1 period increase by 0.132 percentage point. Similarly, each increase of one percentage point in PS will diminish GDP in the lag 1 period by 0.119 percentage point. To sum up, not only has the development of Internet Finance brought new impetus to economic growth, but it has also speeded up the fund flow and the prevalence of Internet payment tools.

\section{VEC Model between PS and CPI}

Likewise, it can be calculated that the optimal lag order of the VEC model is first order and the VEC (1) model is stationary. The co-integration equation between PS and CPI with error correction terms is as follows:

$$
E C M_{t-1}=C P I-0.222 P S-303.1097
$$

Based on the short-term dynamic relationship, the Vector Error Correction model is built as follows:

$$
\left(\begin{array}{l}
\Delta C P I_{t} \\
\Delta P S_{t}
\end{array}\right)=\left(\begin{array}{c}
-0.00034 \\
11.98446
\end{array}\right) E C M_{t-1}+\left(\begin{array}{c}
0.768-0.0008 \\
-0.030 .28723
\end{array}\right)\left(\begin{array}{l}
\Delta C P I_{t-1} \\
\Delta P S_{t-1}
\end{array}\right)+\left(\begin{array}{l}
1.980020 \\
1342.575
\end{array}\right)
$$


Print ISSN: 2053-4086(Print), Online ISSN: 2053-4094(Online)

According to the co-integration equation, the elasticity of CPI on PS is 0.222 , which illustrates that for every change of $1 \%$ in PS, CPI will go up by $0.222 \%$ in the long run. It shows that the development of Internet Finance has boosted the consumption growth in the long term and facilitated residents in payment, which results in rising consumption demand. In the short run, the estimated coefficients of the error correction term (ECMt-1) give the information that when short-term fluctuations deviate from the long-term equilibrium on account of external interference factors, the error correction term will voluntarily turn back to the long-term equilibrium state with the strength of 0.00034 . Namely, the change of CPI in period $t$ can eliminate non-error equilibrium by $0.034 \%$ in the previous period. When it comes to the difference term, the coefficients of CPI and PS in the first-phase regression are -0.03 and -0.0008 , separately, which demonstrates that each increase of one percentage point in CPI will lessen PS in the lag 1 period by 0.03 percentage point. Inversely, each increase of one percentage point in PS will diminish CPI in the lag 1 period by 0.0008 percentage point. In total, Internet Finance has improved the convenience of payment, promoted the efficiency of the consumption system as well as raised the living standards. However, while the currency circulation is speeding up, the currency multiplier increases accordingly and the financial friction of the bank credit system diminish too, which reduces the effectiveness of monetary policy.

\section{Impulse response function of variables}

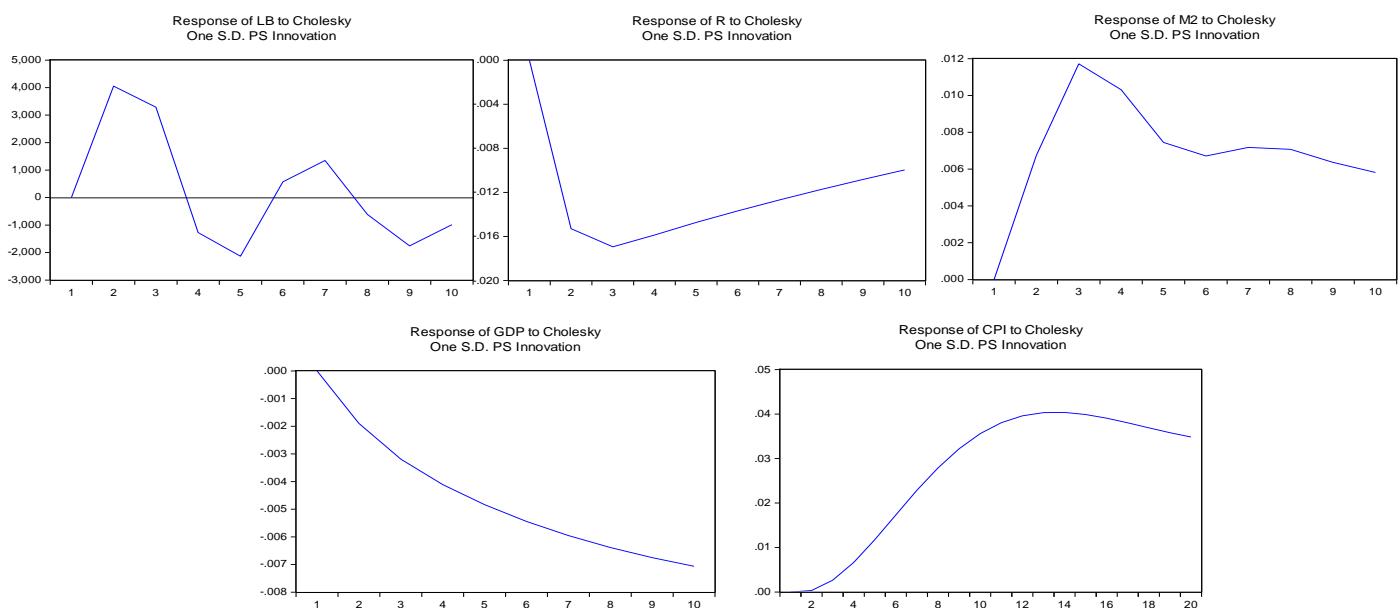

Figure 4. Impulse Response Function of LB, R, M2, GDP and CPI Shocked by PS

As can be clearly seen from Figure 4, when PS positively strikes LB by a standard deviation, there is a dynamic process with alternating ups and downs in the short term. Nonetheless, the impact of Internet Finance flattens out in the long run. It shows that with the development of the supervisory system and interest rate liberalization, the impact of Internet Finance on loans becomes relatively stable, which weakens the role of deposit reserve and thus affects the effectiveness of monetary policy. It is also available that the impact of Internet Finance on interest rates is tiny, indicating that Internet Finance influences the controllability of monetary policy mainly through bank credit channels. On the contrary, Internet 
European Journal of Accounting, Auditing and Finance Research

Vol.8, No.2, pp.1-19, February 2020

Published by ECRTD-UK

Print ISSN: 2053-4086(Print), Online ISSN: 2053-4094(Online)

Finance has a greater influence on money supply, which affects the effect of money supply as an intermediary variable and reduces the measurability and the effectiveness of monetary policy. Moreover, on account of the weak controllability of Internet Finance and the immaturity of the supervision system, the development of Internet Finance has limited economic growth, resulting in endogenous nature of monetary policy. Finally, the development of Internet Finance has led to price fluctuations and rises, which goes against the goal of price stability.

Variance Decomposition between Variables

Table 7. the Result of Variance Decomposition between Variables

\begin{tabular}{lllllllllll}
\hline Period & $\begin{array}{l}\text { Loan balance } \\
\text { of financial } \\
\text { institution }\end{array}$ & \multicolumn{2}{l}{ Interest rate } & \multicolumn{3}{l}{ Money supply } & \multicolumn{2}{l}{$\begin{array}{l}\text { Gross } \\
\text { domestic } \\
\text { product }\end{array}$} & \multicolumn{3}{l}{$\begin{array}{l}\text { Consumer } \\
\text { price index }\end{array}$} \\
\cline { 2 - 14 } & LB & PS & R & PS & M2 & PS & GDP & PS & CPI & PS \\
\hline $\mathbf{1}$ & 100 & 0 & 100 & 0 & 100 & 0 & 100 & 0 & 100 & 0 \\
\hline $\mathbf{2}$ & 96.931 & 3.069 & 99.799 & 0.201 & 93.148 & 6.852 & 99.583 & 0.417 & 99.975 & 0.025 \\
\hline $\mathbf{3}$ & 95.439 & 4.561 & 99.702 & 0.299 & 81.436 & 18.564 & 99.676 & 0.324 & 99.278 & 0.722 \\
\hline $\mathbf{4}$ & 95.418 & 4.582 & 99.665 & 0.335 & 77.274 & 22.726 & 99.253 & 0.747 & 96.793 & 3.207 \\
\hline $\mathbf{5}$ & 95.718 & 4.282 & 99.654 & 0.346 & 79.053 & 20.947 & 98.960 & 1.040 & 91.683 & 8.317 \\
\hline $\mathbf{6}$ & 96.583 & 3.417 & 99.654 & 0.346 & 81.701 & 18.299 & 98.799 & 1.201 & 83.755 & 16.245 \\
\hline $\mathbf{7}$ & 96.782 & 3.218 & 99.660 & 0.340 & 83.330 & 16.670 & 98.654 & 1.346 & 73.677 & 26.323 \\
\hline $\mathbf{8}$ & 96.976 & 3.024 & 99.669 & 0.331 & 84.514 & 15.486 & 98.512 & 1.488 & 62.755 & 37.245 \\
\hline $\mathbf{9}$ & 97.053 & 2.947 & 99.680 & 0.320 & 85.756 & 14.244 & 98.375 & 1.625 & 52.356 & 47.644 \\
\hline $\mathbf{1 0}$ & 97.338 & 2.662 & 99.691 & 0.309 & 86.977 & 13.023 & 98.236 & 1.764 & 43.393 & 56.607 \\
\hline $\mathbf{1 1}$ & 97.570 & 2.430 & 99.703 & 0.297 & 88.020 & 11.980 & 98.093 & 1.907 & 36.194 & 63.806 \\
\hline $\mathbf{1 2}$ & 97.669 & 2.331 & 99.715 & 0.285 & 88.878 & 11.122 & 97.945 & 2.055 & 30.663 & 69.337 \\
\hline $\mathbf{1 3}$ & 97.656 & 2.344 & 99.726 & 0.274 & 89.617 & 10.383 & 97.793 & 2.207 & 26.510 & 73.490 \\
\hline $\mathbf{1 4}$ & 97.688 & 2.312 & 99.737 & 0.263 & 90.273 & 9.727 & 97.635 & 2.365 & 23.404 & 76.596 \\
\hline $\mathbf{1 5}$ & 97.743 & 2.257 & 99.748 & 0.252 & 90.849 & 9.151 & 97.473 & 2.527 & 21.060 & 78.940 \\
\hline
\end{tabular}

It can be concluded from Table 7 that: (1) Loan balance of financial institutions (LB): In its decomposition of mean square error, the contribution rate of self-fluctuation in the first period is the highest $(100 \%)$, indicating that PS in the lag 1 period doesn't affect LB. As the number of lags rises to 4, LB is interpreted by PS to the highest degree and the degree slowly declines with the increase in the number of periods. It can also be seen that LB is mainly affected by itself since banks have been ingrained in indirect financing. The addition of Internet Finance poses new challenges to bank credit, but its impact is minor. (2) Interest rate (R): By analogy, it is found that the main cause of interest rate is interest rate itself, and the development of Internet Finance is proved to have small influence on interest rates. Therefore, the development of Internet Finance mainly affects the bank credit transmission channels, but not the interest rate transmission channels. (3) Money supply (M2): It is also known that the prime influencing factors of M2 are money supply itself and the developmental level of Internet Finance. The impact of Internet Finance on 
Print ISSN: 2053-4086(Print), Online ISSN: 2053-4094(Online)

money supply is huge. The currency derivation mechanism of Internet Finance is justified to weaken the effectiveness of monetary policy. (4) Gross domestic products (GDP): GDP is mainly explained by itself. Internet Finance cannot essentially affect the economic growth. Its development only causes sharp fluctuations in the currency multiplier and money supply, and it cannot practically affect domestic outputs. (5) Consumer Price Index (CPI): Both CPI itself and Internet Finance contribute to the change of CPI. Internet Finance has driven the growth of demand from consumer group, causing prices to rise continuously in the long term. Meanwhile, it also affects the ultimate goal of price stability in monetary policy and reduces the effectiveness of monetary policy.

In summary, the development of Internet Finance does affect the effectiveness of monetary policy through bank credit transmission channels rather than interest rate transmission channels. From bank credit transmission channels, it reduces financial frictions, raises the currency multiplier as well as affects the measurability and controllability of monetary policy, ultimately causing the fluctuations of output, increasing prices and diminishing effectiveness of monetary policy.

\section{CONCLUSION AND SUGGESTION}

\section{Main conclusion}

First, the development of Internet Finance has weakened the effect of bank credit transmission channels in monetary policy. This paper believes that the premise of bank credit transmission channels functioning is that there are frictions in the finance market. The development of Internet Finance does provide a direct financing channel for both supply and demand of funds. In other words, it is a way of reducing the financing cost of enterprises to speed up the capital circulation, thus affecting the status of intermediary functions of commercial banks. The time from the fourth quarter of 2014 to the fourth quarter of 2016 witnessed the decline in the growth rate of deposit balances from $2.6 \%$ to $2.3 \%$ and the decline in the growth of loan balances from $1.5 \%$ to $1.3 \%$ in financial institutions. There was an increase of $2.2 \%$ in the deposit balances and another increase of $0.7 \%$ in loan balances in financial institutions. The information shows that the business of bank credit has shrunk lately. On one hand, the supervision in the finance market become more stringent, and bank credit is also regulated. On the other hand, the development of Internet Finance leads to the transfer of deposits and loans business in banks, causing that the central bank cannot comprehensively monitor the funds flow in Internet Finance. Thus, the development of Internet Finance has reduced financial frictions and weakened the ability of the central bank to regulate monetary policy through the assets and liabilities in commercial banks, which greatly diminishes the effectiveness of bank credit channels in monetary policy.

Second, the development of Internet Finance has reduced the controllability and measurability of money supply. For one thing, with plenty of products in Internet Finance gradually accepted, money from residents flows to online money funds and other areas. Simultaneously, online loans(P2P) also accelerate the expansion of the 
Print ISSN: 2053-4086(Print), Online ISSN: 2053-4094(Online)

deposit and loan business. In the long run, Internet Finance has dramatically shocked the functions of traditional currencies and has challenged the monopoly position of money supply from the central bank. For another, the continuous introduction of new products in Internet Finance threatens the role of monetary policy as a quantitative and price tool. Internet Finance enlarges quantitative monetary policy tools, where the currency generation mechanism reduces the measurability and controllability of money supply, and improves the market endogenous nature of money supply. Hence, the development of Internet Finance influences the intermediate variable(M2) of monetary policy, thereby diminishing the effectiveness of monetary policy no matter in the short or long term.

Third, Internet Finance has affected the ultimate goal of monetary policy. On one side, economic growth gives rise to the development of the Internet. Internet Finance boosts rapidly with the assistance of new platforms, but doesn't dramatically promoted the growth of domestic output in the short term. It is mainly because finance marketization in China is not consummate enough. On the other side, Internet Finance results in price fluctuations in the short run and raise the price in the long term for the reason that Internet payment brings about great convenience of payment, stimulates the growth of demand from the consumer, but hinders the goal of monetary policy to stabilize the price. Therefore, the development of Internet Finance impairs the central bank's regulation in the macro economy, which greatly reduces the effectiveness of monetary policy indeed.

Fourth, in general, the development of Internet Finance has changed the sensitivity of corporate investment to bank credit supply. Besides, it weakens the function of bank credit channels and impedes the realization of the intermediate and ultimate goals of monetary policy.

\section{Policy Suggestion}

First, it is of great significance to deepen the reform of state-owned commercial banks and promote the development of small and medium-sized financial institutions in order to reinforce the effect of bank credit transmission channels of monetary policy. There are several ways of supervision: Initially, it is suggested that stateowned commercial banks review their strengths and weaknesses, actively cooperate with modern financial technology and carry out deposit and loan business for corporates and residents in new ways, which can help to increase the effectiveness of monetary policy. Additionally, it is supposed to drive small and medium-sized financial institutions to legally develop new products that cater to regional capital needs so as to improve the effectiveness of currency supervision. Finally, traditional commercial banks should make good use of science and technology and cooperate with fintech to improve the efficiency of idle funds with the goal of promoting rational allocation of resources.

Second, what we should do is to optimize the macro-control capabilities of monetary policy. To begin with, we should ensure the effectiveness of the bank credit transmission channels, incorporate the changes in the various modes of Internet Finance into the credit transmission mechanism and strengthen the supervision of 
European Journal of Accounting, Auditing and Finance Research

Vol.8, No.2, pp.1-19, February 2020

Published by ECRTD-UK

Print ISSN: 2053-4086(Print), Online ISSN: 2053-4094(Online)

various channels to ensure the effective transmission of monetary policy. Then, the intermediate goal of money supply should be optimized. The central bank can conduct formal statistics with different calibers on the mainstream modes of Internet Finance to improve the measurability and controllability of money supply. Eventually, the ultimate goal of money supply should also be optimized. The impact of the new financial form of Internet Finance on the endogenous nature of currency should be reduced to prevent price and economic fluctuations in a short-term period, thereby improving the effectiveness of monetary policy.

Third, the development of Internet Finance should be encouraged and guided with accurate positioning. At the beginning, it is unrealistic to boost economic growth with Internet Finance as a new driving force in the short term. Economic growth still depends largely on the development of the real economy while the new way of capital circulation can only serve as an auxiliary means. In the second place, incentive mechanisms or policy restraint mechanisms should be established to guide the funds to flow healthily and continuously on the Internet platform. Meanwhile, the coverage of monetary policy on Internet Finance ought to be enlarged to improve the effectiveness of monetary policy. Lastly, it is necessary to ensure the establishment of the product pricing mechanism in Internet Finance, promote the maturity of the pricing mechanism in the finance market and guide the development of the price-based monetary policy mechanism to realize the goal of pushing interest rate liberalization with Internet Finance and establishing a new financial system.

Fourth, there is a need that we should standardize the development of Internet Finance strictly and solve the problem of information asymmetry effectively. On the initial stage, laws and regulations should be actively improved. To give an illustration of it, we should specifically formulate regulations for Internet Finance and create a positive ecological finance environment. What's more, it is encouraged to implement a real-name authentication system for Internet Finance participants and a stricter market access system, and promote the construction of the government credit reporting system so that the government can monitor all the links in Internet Finance with higher efficiency and investigate risks timely. Last but not least, there is a must to improve the rights protection and risk control awareness of investors and corporates to ensure that users of the Internet can reflect problems in time and the government solves problems efficiently, giving better play to the advantages of financial services.

\section{References}

Tao Yana. (2013) Research on Internet Finance Development, Financial Development Review. (11): 8-73.

Yang Miaomiao. (2015) China's Internet Finance Development Problems and Countermeasures, Modern Economic Information. (07): 1-2.

Feng Xinyi. (2018) Research on the definition and statistical methods of Internet Finance, Mathematics Learning and Research. (12): 19-20.

BIS. (1996) Survey of Electronic Money, BIS and The Group of Comput Experts. 17-21.

David Cronin and Kevin Dowd. (2001) Does Monetary Policy Have a Future, Cato 
European Journal of Accounting, Auditing and Finance Research

Vol.8, No.2, pp.1-19, February 2020

Published by ECRTD-UK

Print ISSN: 2053-4086(Print), Online ISSN: 2053-4094(Online)

Journa1. (21): 227-244.

Slovine, Marko. (2006) Digital Money and Monetary Policy, Vo1.XIV, (3):49-54.

Fujiki, Tanaka. (2014) Curneney demand, new technology and the adoption of electronic money: Ev-idence using individual household data, Economics letters. (1):65-78.

Zhong Huigen. (2014) The Impact of Internet Finance on the Central Bank's Monetary Policy and Countermeasures, Financial Economy. (18): 125-126.

Yan Meina. (2015) The Impact of Internet Finance on Monetary Policy and Its Countermeasures, Financial Economics. (22): 16-18.

Liu Lanxun, Qi Yanlong, Zhang Jingjia. (2016) The Impact of Internet Finance on the Effectiveness of Monetary Policy: An Economic Analysis Based on a Micro-banking Framework, Finance and Economics. 37 (01): 61-73.

Gu Haifeng, Zhu Lili. (2018) The Impact of Internet Finance on the Effectiveness of Monetary Policy: Literature Review and Research Prospects, Financial Theory Exploration. (01): 73-80.

Liu Shasha. (2016) Study on the Effectiveness of Monetary Policy Tools in the Background of Financial Disintermediation: Master's Degree Thesis, Lanzhou University.

Shen Juan. (2017) Research on the Impact of Internet Finance on China's Monetary Policy Bank Credit Channel: Master's Degree Thesis. Zhejiang Sci-Tech University.

Zhan Minghua, Zhang Chengrui, Shen Juan. (2018) Development of Internet Finance and Bank Credit Channel Transmission of Monetary Policy, Economic Research. (04): 63-76.

Xiong Zongjun. (2018) Empirical Research on the Impact of Internet Finance Development on the Effectiveness of Monetary Policy: Master's Degree Thesis, Chongqing Technology and Business University.

\author{
Abbreviations: \\ Internet payment transaction scale: PS \\ RMB loans balance of financial institutions: LB \\ Interest rate/ Shibor: R \\ Money supply: M2 \\ Gross domestic product: GDP \\ Consumer price index: CPI
}

